\title{
PRAKTIK KHITHBAH DI MADURA PERSPEKTIF HUKUM ISLAM DAN HUKUM ADAT
}

\author{
Suhaimi \\ Jurusan Syari'ah STAIMU Panyeppen Pamekasan, Komplek \\ Pondok Pesantren Panyeppen Pamekasan, \\ email: suhaimi@yahoo.co.id
}

\begin{abstract}
Abstrak:
Sebelum perkawinan dilakukan, baik secara hukum maupun adat harus didahului dengan khithbah. Laki-laki dan perempuan yang masih dalam ikatan peminangan tentu saja status hukumnya "ajnabiyah". Fenomena yang berkembang di masyarakat terjadi pergeseran dan pengaburan status hukum yang seolah-olah hubungan keduanya telah mempunyai ikatan yang sah menurut hukum Islam. Sehingga tidak terbatasi lagi hubungan antara laki-laki dan perempuan, bahkan masyarakat melakukan praktik peminangan yang menyalahi ketentuan hukum Islam.
\end{abstract}

\begin{abstract}
:
Before a marriage is done, both law and custom must be preceded by khithbah. The boy and girl who still have peminangan relation, of course, their law status are "ajnabiyah". This developing phenomenon in society has friction and vagueness of law status as if their relation have legal relation based on islamic law. It makes their relation have no limit, even the society do the practice of peminangan that violates islamic law certainty.
\end{abstract}

Kata Kunci:

Khithbah, Hukum Islam, Hukum Adat 


\section{Pendahuluan}

Istilah khithbah merupakan konsep fikih yang dalam bahasa kesehariannya disebut dengan peminangan. ${ }^{1}$ Peminangan dapat pula dimaknai permintaan. Khithbah atau peminangan merupakan pernyataan atau permintaan dari seorang laki-laki kepada seorang perempuan untuk mengawininya atau menikahinya, baik dilakukan oleh laki-laki itu secara langsung maupun melalui perantara pihak lain yang dipercayainya sesuai dengan ketentuan agama. ${ }^{2}$ Permintaan ini dipastikan tidak hanya pada seorang laki-laki saja, melainkan juga dapat dilakukan oleh seorang perempuan untuk melamar terlebih dahulu kepada laki-laki. ${ }^{3}$

Khithbah dilakukan mendahului proses pertunangan. Stadium pertunangan ini timbul setelah adanya persetujuan antara kedua belah pihak (pihak keluarga bakal suami dan pihak keluarga bakal isteri) untuk mengadakan perkawinan. Dan persetujuan ini dicapai oleh kedua belah pihak setelah

1 as-Sarqawi dan Zakaria al-Ansori, al-Sharqawi 'ala al-Tahrir, Juz 2 (Jeddah: al-Nashru wa at-Tauzi', tt.), hlm. 243.

2 Sayyid Sâbiq, Fiqh al-Sunnah, Juz 2 (Beirut: Dar al-Fatah al-'Arabi, 1999), hlm. 16. Dan dapat dilihat pada Abu Buraidah M. Fauzi, Meminang dalam Islam (Jakarta: Pustaka al-Kautsar, 2009), hlm. 11. Secara realita ketika melihat adat yang ada di Pamekasan khususnya dan Madura pada umumnya, apabila seorang laki-laki hendak meminang seorang perempuan maka suatu keharusan untuk sedapatnya meminang dengan melalui perantara orang lebih sepuh. Bisa dengan orang tuanya secara langsung atau dengan pihak sepuh yang masih ada ikatan keluarga, atau ketika tidak ada lagi keluarga yang bisa untuk melakukan peminangan, maka bisa meminta tolong pada orang lain yang dianggap tokoh atau dituakan oleh masyarakat. Hal ini dilakukan untuk menjaga adab atau kesopanan. Dan juga untuk membuktikan keseriusan seorang laki-laki untuk bakal mengawini seorang perempuan.

${ }_{3}$ Namun kebiasaan yang muncul di Madura kebanyakan pihak laki-laki yang melamar perempuan dan bukan sebaliknya. Karena sangat tidak lumrah dilakukan ketika seorang perempuan melamar terlebih dahulu kepada laki-laki. Dalam pandangan mereka untuk menjaga nama baik keluarga dan menjaga gengsi supaya tidak muncul persepsi bahwa anak perempuannya telah terkesan "murahan". 
terlebih dahulu ada suatu lamaran, yaitu permintaan yang dilakukan oleh pihak laki-laki kepada pihak perempuan. ${ }^{4}$ Namun ketika tidak adanya persetujuan dari kedua belah pihak, maka proses pertunangan tidak mungkin terjadi, sehingga pernikahan yang didambakan tidak terwujud sebagaimana yang diharapkan.

Laki-laki yang hendak mengawini seorang perempuan, merupakan keharusan baginya untuk mengkhithbah perempuan tersebut sesuai dengan cara khithbah yang telah ditentukan oleh hukum Islam maupun hukum adat. Proses khithbah ini dilakukan setelah melalui tahapan berpikir secara matang dan kebulatan tekad dari seorang laki-laki yang tertarik kepada seorang perempuan dengan niat yang tulus untuk menikahinya.

Adapun yang menjadi tujuan dari khithbah, tidak lain adalah untuk mengikat pihak perempuan (calon isteri) supaya tidak terlebih dahulu dipinang orang lain. ${ }^{5}$ Dengan adanya peminangan berarti suatu pertanda bahwa perempuan tersebut telah ada yang mengikat, dan tidak dibenarkan untuk menerima kembali lamaran laki-laki lain. Begitu juga laki-laki yang hendak meminang perempuan, tidak diperbolehkan meminang perempuan yang sudah dipinang orang lain.

Pada konteks di atas secara jelas dinyatakan tentang tujuan dari khithbah yang sebenarnya menurut ketentuan hukum Islam. Namun tujuan ini banyak yang disalahpersepsikan oleh masyarakat Madura. Bahkan mereka melakukan praktik peminangan yang tidak sesuai dengan hukum Islam. Suatu misal, masyarakat beranggapan bahwa khithbah adalah suatu simbol ikatan agar laki-laki dan perempuan yang melakukan hubungan saling mencintai mendapat pengakuan dari masyarakat, serta agar terhindar dari

\footnotetext{
${ }^{4}$ Soerojo Wigdjodiporo, Pengantar dan Asas-Asas Hukum Adat (Jakarta: PT. Toko Gunung Agung, 1968), hlm. 124.

5 Tim Redaksi Tanwir al-Afkar, Fikih Rakyat; Pertautan Fikih dengan Kekuasaan (Yokyakarta: LKiS, 2000), hlm. 209.
} 
fitnah dan pembicaraan yang negatif dari orang lain. Ketika tidak diikat dengan ikatan khithbah, laki-laki dan perempuan dalam pandangan masyarakat tidak memiliki hak apa pun, kecuali hanya berstatus hukum "ajnabiyah".6 Penyimpangan praktik khithbah dapat dilihat juga dari cara meminang yang melampaui ketentuan hukum Islam.

Di samping itu laki-laki dan perempuan yang tidak memiliki hubungan pertunangan, dalam artian masih belum dikhithbah oleh laki-laki yang mencintainya, maka hal ini akan menjadi bahan pembicaraan orang lain dan bahkan dianggap melakukan perbuatan yang tidak baik. Akan tetapi bilamana sudah dalam ikatan peminangan, maka persepsi masyarakat menjadi berbeda dengan sebelumnya. Sekalipun berjalan berdua bersama tunangannya, atau bahkan berboncengan berdua dan berbicara berdua maka masyarakat cenderung tidak membicarakannya. Karena mereka menganggap laki-laki dan perempuan tersebut sudah bertunangan. ${ }^{7}$ Ini merupakan suatu bentuk kesalahan persepsi yang semestinya tidak perlu terjadi. Untuk itu faktor penyebab atau latar belakang terjadinya anggapan yang salah tersebut perlu diteliti dan dianalisis lebih jauh. Sehingga bila sudah diketahui akar penyebabnya, maka perlu dicari jalan keluarnya yang terbaik agar persepsi yang salah tersebut tidak terjadi lagi. Dan masyarakat dapat memahami secara komprehensip tentang khithbah yang sebenarnya dalam perspektif hukum Islam.

Hukum Islam membolehkan bagi laki-laki yang meminang untuk melihat terlebih dahulu perempuan yang

\footnotetext{
${ }^{6}$ Ibid. hlm. 201. Hukum Ajnabiyah adalah hukum yang mengatur pergaulan laki-laki dan perempuan yang bukan mahram. Seperti larangan berduaan tanpa ada pihak ketiga dari keluarganya, melihat aurat laki-laki atau perempuan, dan banyak lagi contoh yang lainnya.

${ }^{7} \mathrm{Hal}$ ini menjadi sangat bertentangan dengan hukum Islam. Secara hukum Islam, apabila laki-laki dan perempuan berjalan berdua tanpa didampingi oleh mahram, maka haram hukumnya. Apalagi sampai berdua, berbicara atau bersepi-sepi tanpa didampingi mahram.
} 
hendak dipinang, dengan ketentuan melihat sesuai dengan ketentuan hukum Islam. Seperti ketentuan hanya diperbolehkan melihat wajah dan kedua telapak tangan. Akan tetapi dalam realitanya, masyarakat banyak yang tidak memperhatikan ketentuan tersebut. Mereka sebagian besar cenderung kurang memahami tentang hukum Islam. Hukum Islam hanya dipandang sebelah mata tidak dipahami secara utuh, atau bahkan sekalipun sudah dianggap mengerti hukum Islam, akan tetapi tidak menerapkan dalam tataran realita.

Dalam melihat perempuan yang dipinang banyak sekali yang tidak mengindahkan hukum Islam. Dalam realitanya yang terjadi di masyarakat, mereka sudah mengenal terlebih dahulu, bahkan sudah mengenal lebih jauh, yang dalam bahasa sekarang "berpacaran". Pacaran dalam pandangan penulis, merupakan suatu bentuk hubungan laki-laki dan perempuan secara tersembunyi tanpa sepengetahuan orang tua masingmasing. Namun dalam kenyataannya terdapat juga yang berani terang-terangan menampakkan hubungan kemesraannya di hadapan umum. Seperti berjalan berdua, berboncengan menaiki motor atau bahkan berdua di tempat-tempat umum tanpa didampingi mahram. Mereka menampakkan hubungan menyamai hubungan suami isteri.

Melihat perempuan yang dipinang bukan merupakan hal yang tabu lagi, karena sebagian besar mereka sudah mengenal perempuan yang akan dipinang sebelumnya. Hubungan yang ketika ditinjau dari pandangan hukum, sudah di luar kewajaran. Serta bilamana ditinjau dari perspektif moral, hubungan mereka sudah masuk dalam kategori tindakan yang amoral.

Masyarakat Madura dalam melakukan praktik peminangan cenderung meniru kebiasaan yang sebenarnya tidak perlu dilakukan. Misalnya, melakukan tukar cincin antara laki-laki dan perempuan yang dalam masa pertunangan. Dalam proses tukar cincin, mereka melakukannya sendiri sehingga ada saling sentuh tangan antara laki-laki dan perempuan yang 
belum sah secara syar'i. Apabila ditinjau dari hukum Islam, praktik seperti itu tidak diperbolehkan.

Suatu hal lagi yang sangat unik dalam praktik khithbah pada masyarakat Madura dan menunjukkan ciri pembeda dengan daerah-daerah yang lainnya adalah dalam proses peminangan harus disertai dengan berbagai hal yang menjadi pensyaratan secara adat. ${ }^{8}$

Adapun dalam proses peminangan, laki-laki yang meminang perempuan, di samping mengikutsertakan orang tuanya atau walinya untuk meminang dan menurut tradisi yang ada di Madura pihak laki-laki juga harus membawa semacam tanda pangestu. ${ }^{9}$ Yaitu membawa makanan berupa kue-kue yang sudah ditentukan dan biasa diberikan ketika peminangan dilakukan seperti kue wajik dan tettel. ${ }^{10}$ Sebagai variasinya dapat disertakan kue lain sebagai pelengkap.

Di samping itu yang lebih menentukan lagi sebagai tanda sahnya ikatan pertunangan adalah laki-laki harus menyertakan sirih dan pinang muda. ${ }^{11}$ Bilamana sudah ada kedua hal tersebut maka pertunangan sudah dinyatakan resmi, dan perempuan yang sudah dipinang tidak diperbolehkan menerima pinangan laki-laki lain sebagaimana ketentuan dalam hukum Islam dan sekaligus menurut hukum adat.

\footnotetext{
8 Maksud pensyaratan secara adat yaitu mengikuti tradisi yang berlaku dalam masyarakat tersebut, yang bagaimanapun caranya syarat tersebut harus ada untuk dinyatakan sah dalam peminangannya.

9 Tanda pangestu dalam bahasa Madura disebut dengan "pangestoh", yaitu semacam oleh-oleh yang diberikan kepada pihak keluarga perempuan yang tujuannya agar lebih mengikat tali persaudaraan. Sekaligus juga sebagai tanda pengikat pertunangan.

10 Kue-kue tersebut sudah terbiasa diberikan ketika meminang seorang perempuan. Dalam bahasa Madura kue-kue itu disebut bajik dan tettel. Bajik adalah semacam kue yang terbuat dari beras ketan, rasanya manis dan biasanya diberi warna merah atau biru. Sedangkan tettel adalah semacam kue yang juga terbuat dari tepung ketan, biasanya tidak dikasih warna.

${ }^{11}$ Dalam bahasa Madura disebut dengan "sere penang".
} 
Fenomena di atas menunjukkan bahwa masyarakat Madura dalam melakukan praktik khithbah tidak mengacu pada ketentuan hukum Islam, akan tetapi banyak mengacu pada hukum adat. Mereka memiliki persepsi yang sangat keliru dan perlu diluruskan. Ketika hal ini dibiarkan, tanpa adanya upaya untuk meluruskan, maka sama halnya dengan merubah ketentuan hukum yang telah digariskan oleh Islam. Oleh karena itu, upaya memberikan kejelasan tentang praktik khithbah yang benar sangat diperlukan. Hal ini menjadi tugas dan tanggung jawab kita sebagai umat Islam pada umumnya dan peneliti pada khususnya.

\section{Pengertian Khithbah}

Kata khithbah berasal dari bahasa Arab (الخطبة) yang artinya pinangan, lamaran atau meminang. ${ }^{12}$ Lebih spesifik dinyatakan sebagai peminangan. ${ }^{13}$ Secara linguistik peminangan berasal dari kata "pinang" dengan mendapat imbuhan pe - an. Peminangan diartikan proses, cara atau perbuatan meminang. ${ }^{14}$

Khithbah merupakan suatu aktifitas sebagaimana halnya duduk dan berkumpul. Anda berkata, seseorang melakukan khithbah (meminang) terhadap seorang perempuan. Artinya, dia meminang dan mengajak perempuan (yang dipinangnya) untuk

12 Ahmad Warson Munawwir, Kamus al-Munawwir (Surabaya: Pustaka Progressif, 1997), hlm. 349.

13 Dalam konteks orang Madura, proses peminangan ini merupakan permintaan seorang laki-laki kepada seorang perempuan untuk diikat dalam sebuah pertunangan dengan perjanjian dalam waktu tertentu akan dinikahi sesuai dengan kesepakatan dari kedua belah pihak keluarga, baik keluarga dari bakal calon suami maupun keluarga dari bakal calon isteri. Dalam istilah Madura disebut dengan "abakalan".

14 Depdikbud, Kamus Besar Bahasa Indonesia (Jakarta: Balai Pustaka, 1989), hlm. 684 . 
menikah dengan cara yang umum dilakukan orang. ${ }^{15}$

Kalimat رجل خطاب artinya seseorang yang sering mengajukan pinangan. Kata الخطيب artinya seseorang yang meminang perempuan. Kata خطب- يخطب artinya seseorang yang berbicara untuk memberi nasehat atau mencela orang lain. ${ }^{16}$

Secara istilah peminangan merupakan suatu proses atau perbuatan meminang, yang artinya permintaan seorang anak laki-laki kepada anak perempuan orang lain atau seorang perempuan yang ada di bawah kekuasaan seseorang (curator) sebagai pendahuluan dari perkawinan. ${ }^{17}$ Meminang juga diartikan menyatakan permintaan untuk menikah dari seorang laki-laki kepada seorang perempuan atau sebaliknya dengan perantaraan seseorang yang dipercayai. ${ }^{18}$ Setelah peminangan dilakukan dan memperoleh persetujuan dari kedua belah pihak (pihak laki-laki dan perempuan) maka berlangsunglah ikatan peminangan yang biasa disebut dengan pertunangan. Dari ikatan peminangan ini akan sampai pada jenjang perkawinan bilamana tidak terjadi pembatalan ikatan peminangan. ${ }^{19} \mathrm{Jadi}$, dapat dikatakan bahwa ikatan peminangan merupakan proses yang harus dilalui sebelum beranjak pada proses perkawinan.

Dalam kenyataannya, peminangan tidak hanya dilakukan oleh laki-laki saja, akan tetapi dapat dilakukan juga

${ }^{15}$ Sayyid Sâbiq, Figh al-Sunnah, Juz 2, hlm. 16. (Lihat juga: M. Afnan Chafidh dan A. Ma'ruf Asrori, Tradisi Islami, Panduan Prosesi Kelahiran, Perkawinan, Kematian (Surabaya: Khalista, 2006), hlm. 109.

16 Ibid.

17 Kholilah Marhijanto, Menciptakan Keluarga Sakinah (Jakarta: Bintang Remaja, tt.), hlm. 380.

18 Beni Ahmad Saebani, Fiqh Munakahat 1 (Bandung: Pustaka Setia, 2009), hlm. 146.

19 Pembatalan dalam peminangan seringkali terjadi sebelum proses pernikahan dilangsungkan. Hal ini diakibatkan karena adanya beberapa persoalan yang muncul dari pihak bakal calon isteri maupun bakal calon suami, atau bisa jadi berasal dari masing-masing keluarga yang sudah tidak menghendaki sampai pada proses pernikahan. Dalam istilah Madura pembatalan pertunangan ini disebut "burung" (batal). 
oleh perempuan. Namun hal seperti ini jarang sekali terjadi dikarenakan secara adat diharuskan laki-laki yang mendahuluinya. Hal yang dijadikan pertimbangan, ketika peminangan dilakukan dengan menyalahi adat setempat, maka secara pasti akan menimbulkan kesan yang negatif dari masyarakat.

Meminang artinya menyatakan permintaan untuk menikah dari seorang laki-laki kepada seorang perempuan atau sebaliknya dengan perantaraan seorang yang dipercayai, baik peminangan dilakukan terhadap gadis maupun janda yang telah habis 'iddahnya. ${ }^{20}$ Menurut al-Hamdani dalam kitabnya risalah nikah yang dikutip oleh Kholilah Marhijanto, meminang adalah kebiasaan Arab lama yang diteruskan oleh Islam dan peminangan dilakukan sebelum terjadinya akad nikah dan setelah dipilih dan dipertimbangkan secara matang. ${ }^{21}$

Pengertian yang dilontarkan oleh Hamdani ini mengandung penjelasan bahwa sebelum dilakukan proses peminangan, seorang laki-laki yang bermaksud menjalin ikatan perkawinan terhadap seorang perempuan, dianjurkan terlebih dahulu mengetahui secara mantap tentang keadaan diri dan keluarga perempuan yang akan dipinang. Untuk sedapat mungkin mengetahui keadaan perempuan tersebut tidak harus mengetahui dengan jalan upaya sendiri atau meninjau langsung, melainkan melalui kerabat terdekat atau keluarganya. Hal ini dilakukan untuk seyogyanya menghindari timbulnya kemaksiatan, menjaga kehormatan, serta menghindari terjadinya fitnah.

Sayyid Sâbiq memberikan pengertian:

$$
\text { صاحبه ويكون الاقدام على الزواج على هدى مقد وبصهات الله قبل الارتباط بعقد الزوجية ليتعرف كل من الزوجين }
$$

${ }^{20} \mathrm{Abu}$ Buraidah M. Fauzi, Meminang dalam Islam, hlm. 11. (Lihat juga Abd. alMuhaimin As'ad, Risalah Nikah Penuntun Perkawinan (Surabaya: Bintang Terang, 1993), hlm. 25.

${ }^{21}$ Kholilah Marhijanto, Menciptakan Keluarga Sakinah, hlm. 37. 
Khithbah adalah suatu aktifitas yang menjadi pembuka untuk melangsungkan pernikahan. Allah swt. swt. memberlakukan pinangan (sebagai langkah awal untuk menikah) agar orang yang akan melangsungkan pernikahan saling mengenal satu sama lain (antara calon isteri dan calon suami), sehingga diantara keduanya mantap untuk melangsungkan pernikahan. ${ }^{22}$

Mengkritisi dari pengertian yang disinyalir oleh Sayyid Sâbiq, penulis berasumsi bahwa peminangan identik dengan kebiasaan yang terjadi dalam masyarakat. Kebiasaan ini menyangkut proses atau cara dalam melakukan peminangan. Ketika kita berbicara tentang kebiasaan (adat) maka tentu saja antara masyarakat suatu daerah dengan masyarakat daerah lain akan berbeda secara signifikan. Suatu misal, peminangan yang biasa dilakukan di daerah perkotaan, maka peminangan yang dilakukan akan menggunakan cara yang biasa dilakukan di perkotaan. Misalnya, dengan diadakan pesta secara meriah, tukar cincin dan lain sebagainya. Lain halnya dengan peminangan yang biasa dilakukan di daerah pedesaan, maka akan menggunakan kebiasaan di desa yang identik dengan kesederhanaan. Misalnya, dengan acara lamaran yang dilakukan oleh pihak laki-laki dengan membawa segenap sanak famili atau tetangganya ke rumah perempuan yang akan dipinang yang di dalamnya disajikan hidangan yang sangat sederhana. Kebiasaan inilah yang dalam bahasa Madura disebut "letaleh". ${ }^{23}$

berikut:

Wahbah al-Zuhaili memberikan pengertian sebagai

$$
\text { بواسطة اهله. الخطبة هي اظهار الرغبة فن الزواج بامراة وليها بذلك. وقد يتم هذا الاعلام مباشرة الخاطب او }
$$

22 Sayyid Sâbiq, Fiqh al-Sunnah, Juz 2, hlm. 16.

${ }^{23}$ Letaleh merupakan istilah yang biasa digunakan oleh orang Madura untuk mengikat seorang perempuan yang dipinang. Jikalau seorang laki-laki telah melakukan hal ini maka secara resmi mempunyai ikatan peminangan. 
Khithbah adalah pernyataan yang dilakukan kepada seorang perempuan yang dikehendaki untuk dinikahi. Dan setelah mengetahui tentang seluk-beluk perempuan tersebut maka secara langsung melamar atau meminang kepada keluarganya. ${ }^{24}$

Anshari Umar Sitanggal dalam bukunya Fikih Syafi'i Sistematis menyatakan bahwa peminangan akan berlangsung apabila telah diperoleh keyakinan tentang sifat-sifat yang baik pada masing-masing pihak, dan dengan melihat serta memandang telah terjadi kerelaan dan sama-sama suka. ${ }^{25}$ Dalam artian bahwa peminangan akan berlangsung secara selaras dengan tiadanya ganjalan apapun dari kedua belah pihak jikalau dilakukan dengan penuh kerelaan atau atas dasar saling menyukai. Jadi, ikatan peminangan akan terjadi ketika seorang laki-laki telah meminang perempuan yang disukai. Tanpa peminangan, ikatan peminangan tidak akan mungkin terjadi. ${ }^{26}$ Apabila sudah terjadi ikatan pertunangan maka tinggal menunggu saat perkawinan (pernikahan). Mengenai waktu perkawinan para fuqaha' berpendapat bahwa waktunya ketika peminang dan yang dipinang sudah cenderung satu dengan lainnya. Maksudnya ketika sudah menjalin rasa cinta dan keinginan untuk melangkah pada jenjang perkawinan. ${ }^{27}$

Tujuan inti dari peminangan ialah agar seyogyanya kedua calon suami maupun isteri dapat saling mengenal, dapat mengetahui sifatnya masing-masing, serta mengetahui akhlaknya dan seluk-beluk keluarganya masing-masing sebelum melakukan akad nikah, sehingga pelaksanaan

${ }^{24}$ Wahbah al-Zuhailī, al-Fiqh al-Islāmi wa Adillatuh, Juz 7 (Damaskus: Dār alFikr, 2010), hlm. 24.

${ }^{25}$ Ashari Umar Sitanggal, Fiqih Syafi'i Sistimatis (Semarang: As-Syifa', 1994), hlm. 236.

26 Dari sini dapat dikatakan bahwa peminangan merupakan proses awal yang dilakukan sebelum terjadinya ikatan peminangan.

27 Ibnu Rusyd, Bidâyatu al-Mujtahid Wanihâyatu al-Muqtasid, terj. Imam Ghazali Said, Ahmad Zaidun (Jakarta: Pustaka Amani, 2007), hlm. 395-396. 
perkawinannya nanti benar-benar berdasarkan pandangan dan penilaian yang jelas. ${ }^{28}$ Hal ini dimaksudkan agar dalam menjalani kehidupan nantinya, mendapatkan kehidupan yang lebih baik. ${ }^{29}$ Dengan demikian tujuan perkawinan yang menitikberatkan pada tercapainya keluarga sakinah, mawaddah wa rahmah dapat tercapai dengan baik di bawah naungan dan ridha Allah swt. Yang Maha Kuasa.

\section{Syarat-syarat Peminangan}

Laki-laki yang hendak melakukan peminangan tidak secara serta merta bertindak sesuai dengan kemauannya sendiri, melainkan harus memenuhi beberapa persyaratan, karena jika persyaratan ini tidak dipenuhi maka peminangan yang dilakukan tidak baik secara hukum, baik hukum Islam maupun hukum adat, bahkan peminangan yang dilakukan kemungkinan tidak dianggap sebagai peminangan.

Sayyid Sâbiq memberikan persyaratan bahwa laki-laki yang hendak melakukan peminangan harus memperhatikan perempuan yang akan dipinang. Syarat yang harus diperhatikan meliputi dua hal: Pertama, Pada waktu dipinang perempuan tidak ada halangan hukum yang melarang dilangsungkannya perkawinan, misalnya perempuan yang dalam masa 'iddah, perempuan yang masih bersuami, dan lain sebagainya. Kedua, Perempuan yang hendak dipinang tidak sedang dipinang laki-laki lain secara sah. ${ }^{30}$

Dalam persoalan ini Anshori Umar Sitanggal juga mensinyalir tentang kedua syarat yang telah disebutkan di atas yaitu bahwa laki-laki yang boleh meminang perempuan ketika perempuan tersebut tidak ada halangan apapun secara syar'i

\footnotetext{
${ }^{28}$ Sayyid Sâbiq, Fiqh al-Sunnah,hlm. 16.

${ }^{29}$ Wahbah al-Zuhailī, al-Figh al-Islämi wa Adillatuh, Juz 7, hlm. 24.

30Sayyid Sâbiq, Fiqh al-Sunnah,hlm. 16. (Lihat juga: Wahbah al-Zuhailī, al-Fiqh al-Islāmi wa Adillatuh, Juz 7, hlm. 29-31).
} 
dan tidak ada ikatan apapun, baik ikatan perkawinan maupun ikatan peminangan. ${ }^{31}$ Mengenai pembahasan selengkapnya akan dijelaskan pada sub pembahasan tentang perempuan yang tidak boleh dipinang.

Secara rinci tentang syarat perempuan yang boleh dipinang adalah sebagai berikut: ${ }^{32}$ (a) Perempuan yang tidak sedang dalam pinangan orang lain, (b) Tidak sedang dalam masa 'iddah, (c) Tidak ada larangan syar'i untuk dinikahi, dan (d) Perempuan yang sedang masa 'iddah karena ditalak ba'in oleh suaminya, sebaiknya dipinang secara sindiran.

\section{Peminangan dalam Tinjauan Hukum Islam}

Islam telah mengajarkan bagaimana hubungan antara laki-laki dan perempuan, status hukum, dan batasan-batasan hubungan yang diperbolehkan atau tidak diperbolehkan, sehingga tidak mudah bagi seseorang untuk melakukan hubungan secara bebas tanpa melihat nilai-nilai religiusitas dan adat-istiadat yang berkembang di masyarakat. Hukum Islam merupakan pedoman hidup bagi umat Islam secara universal dalam berbagai aspek, baik aspek ekonomi, politik, sosial, budaya maupun hukum. Salah satu aspek yang diatur oleh Islam adalah mengenai peminangan. Peminangan merupakan suatu hal yang dianjurkan oleh Islam dengan berbagai pertimbangan dan tujuan tertentu. Oleh karena itu peminangan merupakan suatu hal yang harus dilakukan bagi seseorang yang hendak melakukan perkawinan, tanpa di dahului oleh proses peminangan, maka perkawinan mustahil dapat dilaksanakan.

Islam telah mengajarkan tentang peminangan, sebagaimana disitir dalam al-Qur'an surat al-Baqarah ayat 235 sebagai berikut:

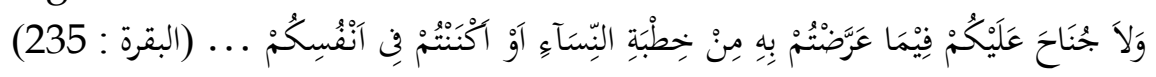

\footnotetext{
${ }^{31}$ Anshori Umar Sitanggal, Figh Wanita (Semarang: as-Syifa', 1981), hlm. 361.
}

32 Beni Ahmad Saebani, Fiqh Munakahat 1, hlm. 149. 
"Dan tidak ada dosa bagi kamu meminang wanita-wanita itu dengan sindiran atau kamu menyembunyikan (keinginan mengawini mereka) dalam hatimu". 33

'Ali al-Shabuni dalam Tafsir Rawai'u al-Bayan menjelaskan, bahwa kandungan yang sebenarnya dari surat alBaqarah ayat 235 yaitu menjelaskan tentang cara meminang wanita yang masih dalam masa 'iddah. Tafsir ini menjelaskan hukum khithbah (meminang) kepada wanita yang ber'iddah setelah ditinggal mati oleh suaminya, namun peminangan ini harus memenuhi ketentuan yang telah ditentukan oleh ajaran Islam, yaitu peminangan dilakukan dengan sindiran, tidak boleh dilakukan dengan terus terang. ${ }^{34}$

al-Shabuni juga menafsirkan bahwa Allah swt. tidak akan mempersempit dan tidak akan menghukumi dosa kepada lakilaki yang menyenangi perempuan dan berkehendak meminangnya, sekalipun perempuan tersebut dalam keadaan 'iddah, dengan syarat memenuhi ketentuan yang telah digariskan oleh syara', yaitu meminang dengan sindiran, cara yang baik, tidak berkata kotor, tidak melakukan kejelekan, dan tidak melakukan perkawinan sampai habis masa 'iddahnya. ${ }^{35}$

Ditinjau dari hukum Islam, peminangan tidak merubah status hukum hubungan antara laki-laki dan perempuan, hanya saja dengan peminangan keduanya memiliki ikatan yang disebut dengan ikatan peminangan (pertunangan). Dalam Islam hubungan laki-laki dan perempuan yang tidak memiliki hubungan mahram diatur dengan sangat ketat. Jangankan sampai berbicara berduaan, memandang sekalipun menjadi

\footnotetext{
33 al-Qur' an, al-Baqarah (2): 235.

34 'Ali al-Shabuni, Rawai'u al-Bayan (Beirut: Maktabah al-Ghazali, $448 \mathrm{H}$ ), hlm. 372.

${ }^{35}$ Ibid.
} 
pelarangan, baik pandangan laki-laki terhadap perempuan maupun pandangan perempuan terhadap laki-laki. ${ }^{36}$

Dalam al-Qur'an surat al-Nur ayat 30 secara implisit maupun eksplisit telah menyinggung mengenai hal ini, sebagaimana bunyi ayatnya:

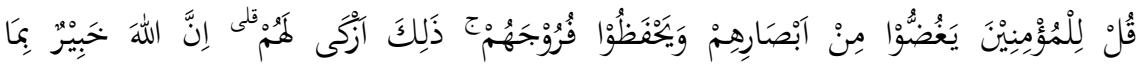

$$
\begin{aligned}
& \text { يَصنَعَعُونَ (النور: 30) }
\end{aligned}
$$

"Katakanlah kepada orang laki-laki yang beriman, "Hendaklah mereka menahan pandangannya dan memelihara kemaluannya", yang demikian itu adalah lebih suci bagi mereka, sesungguhnya Allah swt. Maha Mengetahui apa yang mereka perbuat". ${ }^{37}$

Ayat di atas menerangkan bahwa kita dilarang memberikan pandangan mata kepada lain mahram, baik lakilaki terhadap perempuan maupun perempuan terhadap lakilaki, agar dapat menghindari timbulnya nafsu birahi yang akan menjurus pada perbuatan zina yang merupakan perbuatan yang dilarang oleh Islam, karena termasuk perbuatan keji dan fakhsha'.

Abdullah Gymnastiar mensinyalir bahwa menjaga pandangan terutama bagi kaum laki-laki memang sangat tidak mudah, terbukti tidak sedikit tayangan-tayangan atau sajiansajian media massa yang mudah menggelorakan syahwat. Akibatnya, tidak sedikit laki-laki yang kemudian tergerak

\footnotetext{
36 Pandangan yang dimaksud adalah melihat lain mahram secara berlebihan dengan mengumbar nafsu seksual. Dalam Islam diberikan batasan bahwa pandangan merupakan perbuatan yang tidak mengandung dosa, dalam hal ini tentu saja merupakan pandangan yang tidak menimbulkan nafsu seksual. Pandangan yang pertama merupakan rizki bagi yang memandang. Sedangkan lirikan yang kedua kali merupakan perbuatan dosa yang kemungkinan besar akan mengundang nafsu, hal inilah yang harus dihindari. (Lihat di: Imam Hafidz 'Imaduddin Abi al-Fida' Ismail Ibn 'Umar Ibnu Kathir, Tafsir Ibn Kathir (Beirut Libanon: Dar al-Kutub al-'Ilmiyah, 1971),hlm. 255.

37 al-Qur'an, al-Nur (24): 30.
} 
nafsunya. Masih mending kalau ia sudah mempunyai isteri dan isterinya bisa memahami, kalau tidak maka boleh jadi dia akan mencari sumber yang tidak halal, otomatis saat itu dia terjerumus ke dalam lembah perzinaan. ${ }^{38}$

Ayat ini tidak hanya menganjurkan kita untuk menjaga pandangan mata, akan tetapi juga mengharuskan untuk menjaga kemaluan agar tidak terjerumus ke dalam perbuatan zina. Kemaluan merupakan alat vital ketika tidak dijaga secara ketat dan ekstra hati-hati maka akan menyebabkan kefatalan dalam kehidupan seseorang baik laki-laki maupun perempuan.

Surat al-Nur ayat 30 mengingatkan kepada kita agar senantiasa hati-hati dalam menjaga pandangan dan berhati-hati dalam berhubungan antara laki-laki dan perempuan. Dalam melakukan praktik peminangan perlu adanya kehati-hatian jangan sampai terpengaruh oleh budaya atau tradisi yang tidak sesuai dengan ajaran Islam.

Suatu hal yang perlu diingat bahwa status peminangan tidak berbeda halnya dengan laki-laki dan perempuan yang tidak dalam ikatan peminangan (pacaran), melainkan yang menjadi perbedaan hanya pada faktor tertentu saja yaitu tahu tidaknya pihak keluarga dan pandangan masyarakat. Dan juga yang menjadi perbedaan adalah tentang proses penyatuan kedua belah pihak. Laki-laki dan perempuan yang diikat dengan peminangan seolah-olah mempunyai kebulatan tekad untuk menyatu secara fisik dan mental, sedangkan pacaran mayoritas hanya menyatu secara fisik saja dan mental dikesampingkan. Ada juga yang menyatakan bahwa pacaran di dalamnya terdapat penyatuan secara mental, namun hal itu hanya sebatas ungkapan semu saja (bersifat dramatis). Sedangkan dalam tinjauan hukum Islam status hukum laki-laki

${ }^{38}$ Abdullah Gymnastiar, Meraih Bening Hati dengan Manajemen Qolbu (Jakarta: Gema Insani, 2002), hlm. 44. 
dan perempuan yang dalam ikatan peminangan yaitu, berstatus hukum "ajnabiyah". 39

Status hukum bagi laki-laki dan perempuan yang bukan mahram dan masih belum ada ikatan perkawinan secara sah berdasarkan hukum Islam adalah berstatus hukum "ajnabiyah". ${ }^{0}$ Oleh karena itu, tidak ada ikatan apapun yang bisa meniadakan status hukum tersebut kecuali adanya ikatan mahram dan ikatan perkawinan secara sah. Peminangan hanya berupa perjanjian untuk melakukan perkawinan, karena perkawinan tidak akan sempurna ketika tidak dilakukan dengan akad yang baik antara kedua belah pihak yang bertunangan. ${ }^{41}$

Berkenaan dengan perintah meminang, dijelaskan dalam sebuah hadits yang diriwayatkan oleh Jabir ibn Abdillah yang berbunyi sebagai berikut:

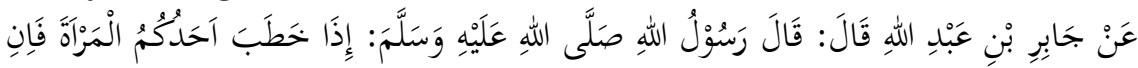

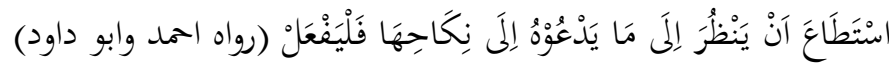

"Dari Jabir ibn Abdillah berkata: bersabda Rasulullah saw. apabila seorang dari kamu sekalian meminang wanita, maka harus dapat melihat sebagian anggota tubuhnya yang dapat menimbulkan rasa ingin mengawininya, maka lakukanlah." (HR. Ahmad dan Abu Daud). ${ }^{42}$

Dalam kitab Aunu al-Ma'bud, Abd. al-Rahman menjelaskan tentang hadits di atas bahwa laki-laki yang hendak

39 Tim Redaksi Tanwirul Afkar, Figh Rakyat Pertautan Figh dengan Kekuasaan, hlm. 210.

${ }^{40}$ Imam Taqiyuddin Abu Bakar, Kifayatu al-Akhyar fi Halli Ghayati al-Ikhtisar, Juz 2 (Bandung: Pustaka al-Ma'arif, tt.), hlm. 42.

${ }^{41}$ Wahbah al-Zuhailī, al-Fiqh al-Islämi> wa Adillatuh, Juz 7, 25.

42 Abd al-Rahman Muhammad Uthma>n, Ainu al-Ma'bu>d, Juz VI (Beiru>t: $\mathrm{Da}>\mathrm{r}$ al-Fikr, tt), 96. Kitab hadits ini adalah kitab sharakh Sunan Abi> Daud, Abi T\{ayyi $>$ b Muhammad Shams al-Haqqu al-Ad\}i $>$ m Abadi dan Sharah alHafiz\} Ibnu Qayyim al-Jauziyah. Muhammad Ibn Isma>'il al-Ami $>$ r alS\{an'a>ni>, Subul al-Sala>m, Juz 3 (Beiru>t: Da>r al-Kutub al-'Ilmiyah, 1971), 112-113. 
meminang perempuan karena ada sesuatu yang menarik dari perempuan tersebut maka dianjurkan untuk segera melakukan peminangan kemudian menikahinya. ${ }^{43}$

Abd. al-Rahman mensinyalir bahwa kata "falyaf'al" pada hadits di atas menunjukkan perintah pembolehan (al-Amru Li alIbahah) yang diperkuat oleh pendapatnya Imam Ahmad. ${ }^{4}$ Dengan adanya perintah pembolehan ini, laki-laki yang berkehendak untuk meminang perempuan agar seyogyanya segera melakukan peminangan sesuai dengan ketentuan hukum Islam.

Dalam Islam telah diajarkan bagaimana cara melakukan peminangan yang Islami yang sesuai dengan prinsip-prinsip ajaran Islam, yaitu peminangan yang tidak mengandung dosa dan perbuatan maksiat. Peminangan yang Islami dapat dilihat dari cara meminang dan juga bisa dilihat dari praktik keseharian selama dalam ikatan peminangan, serta mengetahui segala sesuatu yang merupakan pembolehan atau pelarangan selama melakukan peminangan, seperti mengetahui perempuan yang tidak boleh dipinang, mengetahui bagaimana cara membatalkan ikatan peminangan dan melihat perempuan yang dipinang. ${ }^{45}$

\section{Khithbah di Madura}

Beberapa temuan penelitian yang telah ditemukan di lapangan, peneliti yakin bahwa dengan temuan penelitian saja tidak akan menemukan pemahaman yang kompleks dan integral terhadap esensi khithbah dalam perspektif hukum Islam serta praktik khithbah di Madura. Untuk itu sangat perlu kiranya membahas lebih jauh tentang temuan penelitian yang diperoleh peneliti.

\footnotetext{
${ }^{43}$ Ibid., 96.

${ }^{44}$ Ibid.

45 Pernyataan ini dikeluarkan berdasarkan analisis penulis dengan berpedoman pada literatur, khususnya pada buku karangan M. Thalib, 15 Tuntunan Meminang Islami (Bandung: Irshad Bait al-Salam, 1999).
} 


\section{Praktik Khithbah di Madura.}

Hukum Islam memuat persoalan yang sangat kompleks dalam berbagai aspek dan lini kehidupan baik menyangkut masalah politik, hukum, sosial maupun budaya, termasuk persoalan yang selama ini terjadi dalam kehidupan masyarakat yaitu berkenaan dengan praktik khithbah.

Islam mengajarkan tentang cara peminangan yang Islami yakni peminangan yang tidak melanggar ketentuan hukum syar'i. Laki-laki yang menyukai seorang perempuan hendaknya ia harus mempertimbangkan secara matang dengan mengadakan penyeleksian terhadap keadaan diri perempuan dengan melalui perantara orang lain sebagai informan. Setelah benar-benar terdapat kecocokan kemudian secepatnya dilakukan proses peminangan supaya perempuan yang bersangkutan tidak didahului orang lain untuk melamarnya.

Selama ini praktik yang terjadi dalam masyarakat terutama di Madura menampakkan praktik yang tidak sesuai dengan ketentuan hukum Islam. Sebelum peminangan dilakukan, laki-laki dan perempuan sudah terlebih dahulu mengenal lebih jauh dengan melalui proses yang sering disebut "pacaran". Proses ini ditandai dengan seringnya mengadakan pertemuan di tempat yang tidak diketahui orang lain. Tujuan pertemuan ini, hanya untuk membicarakan persoalan pribadi masing-masing dan juga tidak sedikit hanya dengan tujuan menyalurkan hawa nafsunya. Cara seperti ini tentu saja akan membawa implikasi yang negatif. Pertama, Akan menimbulkan fitnah; Kedua, Kecenderungan untuk melakukan perbuatan maksiat yang mengarah kepada perbuatan zina; Ketiga, Merupakan pelecehan terhadap kesucian harkat dan martabat pemuda dan pemudi muslim yang pada hakekatnya berada dalam kesucian (fitrah).

Setelah khithbah dilakukan dan lamarannya diterima oleh pihak perempuan, maka terjadilah ikatan peminangan. Ikatan peminangan di Madura ditandai dengan lamaran secara resmi yang dalam istilah Madura dinamakan "Le-Taleh". Dalam acara 
ini biasanya laki-laki peminang membawa pihak keluarga dan tetangga untuk pergi ke rumah perempuan yang akan dipinang dengan membawa beberapa jenis kue atau jajan, yang tak kalah pentingnya adalah jajan perawan (Jejen Paraben) yang dijadikan sebagai simbol tanda pengikat khithbah. Dikatakan sebagai tanda pengikat karena pada jajan tersebut dibuat sedemikian rupa bentuknya dan di dalamnya dikasih nama kedua belah pihak yang berpinangan. Setelah lamaran selesai dilakukan, maka resmilah ikatan peminangan.

Laki-laki dan perempuan yang berada dalam ikatan peminangan status hukumnya adalah "ajnabiyah". Artinya hubungan laki-laki dan perempuan yang bukan mahram mempunyai ketentuan atau batas-batas tertentu yang tidak boleh dilanggar. Pelanggaran terhadap ketentuan hukum berarti telah melakukan perbuatan dosa. Tidak ada alasan apapun untuk melakukan tawar-menawar dalam masalah hukum. Islam memberikan hukum haram--tidak akan berubah menjadi halal selama alasan yang diberikan tidak dapat diterima oleh syara'. Namun, dalam situasi dan kondisi tertentu atau dalam keadaan darurat, maka hukum memberikan kelonggaran dari yang tidak boleh menjadi boleh. Akan tetapi, wujud pembolehan juga harus melalui prosedur yang ditentukan oleh syara'.

Sungguh ironis ketika mengamati praktik khithbah di Madura yang cenderung akan merubah status hukum dari peminangan yang sebenarnya menurut hukum Islam menuju kepada praktik khithbah yang disesuaikan dengan kebiasaan (adat/tradisi) yang berkembang di masyarakat. Observasi dan wawancara yang telah dilakukan peneliti ternyata bisa diasumsikan bahwa dengan peminangan mereka sudah beranggapan memiliki hak tertentu terhadap tunangannya, walaupun tidak secara utuh sebagaimana laki-laki dan perempuan yang memiliki ikatan pernikahan secara sah.

Dengan adanya sebagian hak inilah mereka mendapatkan pengakuan dari masyarakat sehingga perbuatan 
apa saja yang dilakukan semasa berada dalam ikatan peminangan, asalkan bukan perbuatan zina, masyarakat sudah tidak mempersoalkan lagi karena mereka beranggapan bahwa itu adalah hal yang biasa.

Hukum dibuat oleh Tuhan untuk mengatur hubungan manusia dengan Tuhannya, hubungan manusia dengan sesamanya dan hubungan manusia dengan alam. Kaitannya dengan peminangan merupakan hubungan manusia dengan sesama yang menghendaki adanya hubungan secara horisontal dengan hidup berdampingan secara damai, harmonis dan jauh dari pelanggaran yang dapat merugikan diri sendiri dan orang lain.

Meminjam bahasanya Fazlur Rahman yang dikutip oleh Ghufron A. Mas'udi bahwa hukum berpijak sebagai legal spesifik yang sifatnya mengikat dan niscaya harus diikuti, namun terkadang hukum dikalahkan oleh realitas atau keadaan sosial yang ada. ${ }^{46}$ Sebagai contoh, hukum khithbah yang sebenarnya secara legal spesifik telah diatur oleh Islam, namun kenyataan yang terjadi di masyarakat tidak sejalan dengan hukum yang telah mengaturnya. Mereka cenderung mengikuti kebiasaan yang berlaku sebelumnya kendatipun menyimpang dari nilai-nilai agama.

Jika kebiasaan jelek ini dibiarkan, maka orang Islam akan meninggalkan hukum agama. Dari sinilah sangat dipentingkan pemahaman hukum yang tidak hanya secara legal spesifik akan tetapi juga memahami hukum secara ideal moral, yaitu suatu pemahaman yang lebih berpijak pada jiwa atau kandungan hukum. Artinya, hukum harus melihat keadaan sosial yang ada yang sejalan dengan perkembangan zaman, waktu dan tempat. Hal ini bukan berarti hukum harus mengikuti zaman, akan tetapi hukum harus bisa menuntun zaman.

\section{Latar Belakang Praktik Khithbah.}

46 Ghufron A. Mas'udi, Pemikiran Fazzlur Rahman Tentang Metodologi Pembaharuan Hukum Islam (Jakarta: RajaGrafindo Persada, 1997), hlm. 123. 
Pada bagian ini peneliti akan membahas hal-hal yang melatarbelakangi adanya praktik khithbah di Madura sebagai berikut: Pertama, Ketidaktahuan sebagian anggota masyarakat Madura terhadap praktik khithbah. Mengamalkan ajaran Islam secara utuh (integral) tentu saja harus memahami ajaran tersebut secara teoritis dan praktis. Tidak sempurna Islam seseorang bilamana hanya mengetahui ajaran Islam secara teori saja tanpa diwujudkan melalui praktik. Justru sebaliknya, praktik tanpa dibarengi teori akan nonsense dapat mempraktikkan secara benar.

Begitu pula praktik peminangan yang selama ini tengah berkembang di Madura. Masyarakat melakukan praktik yang keliru karena faktor ketidaktahuan mereka terhadap praktik yang sebenarnya yang sesuai dengan prespektif hukum Islam, mulai dari cara meminang sampai dengan proses ikatan peminangan berlangsung. Adanya penyimpangan dalam khithbah, peneliti tidak seratus persen menyalahkan masyarakat Madura, karena peneliti telah mengetahui secara objektif bahwa: Pertama, Mereka benar-benar tidak mengetahui praktik khithbah yang dibenarkan menurut hukum Islam. Mereka mempunyai kecenderungan untuk mengikuti praktik khithbah yang sebelumnya sudah berkembang di masyarakat yang sampai sekarang menjadi kebiasaan (tradisi). Kedua, Kurangnya pemahaman masyarakat Madura terhadap peminangan yang dibenarkan oleh hukum Islam. Pemahaman terhadap hukum Islam memang sangat berpengaruh terhadap tingkat ketaatan dan perilaku hidup seorang muslim. Paham terhadap hukum Islam berarti tahu dan mengerti tentang hukum, sedangkan orang yang tidak memahami hukum menunjukkan ketidaktahuannya. Jadi, dapat dikatakan ketidakpahaman identik dengan ketidaktahuan.

Masyarakat Madura cenderung melakukan praktik khithbah yang tidak sesuai dengan hukum Islam, dikarenakan kebanyakan dari mereka tidak mengetahui bahwa status peminangan sama dengan sebelum mereka melakukan 
peminangan. Keduanya (laki-laki dan perempuan) adalah bukan mahram dan diharamkan bagi mereka melakukan pertemuan tanpa dibarengi mahram, baik mahram dari pihak laki-laki maupun dari pihak perempuan.

Kendatipun demikian, ada juga sebagian anggota masyarakat yang mengerti hukum peminangan, hanya cenderung mengikuti arus zaman. Mereka sama sekali tidak memberikan keteladanan dan penerangan tentang hukum kepada masyarakat, bahkan mereka sendiri yang cenderung melakukan tindak pelanggaran.

Ketiga, Kurangnya intensifikasi bimbingan tokoh agama tentang khithbah yang sesuai ketentuan hukum Islam. Peran tokoh agama dalam membimbing dan membina umat Islam sangat diperlukan demi terciptanya kehidupan umat yang dinamis, penuh dengan nilai-nilai religius di bawah ridha Sang Ilahi. Tokoh agama (ulama') merupakan pewaris para nabi yang bertugas menyampaikan secara jelas perkara hak yang harus dilaksanakan dan perkara batil yang harus ditinggalkan.

Sebenarnya banyak tokoh agama yang memahami tentang hukum peminangan menurut hukum Islam sekaligus praktiknya. Namun, masih kurang adanya upaya untuk mensosialisasikan masalah hukum peminangan kepada masyarakat. Kendatipun pernah dilakukan akan tetapi tidak optimal, dikarenakan mereka disibukkan oleh aktifitasnya masing-masing. Seringkali kegiatan yang berupa pengajian digelar, tetapi jarang sekali menyinggung persoalan yang berkaitan dengan khithbah. Materi pengajian yang diberikan hanya berkutat pada persoalan ibadah saja, tidak sama sekali merilis pada persoalan sosial yang berkembang, terutama di Madura.

Keempat, Kecenderungan masyarakat meniru budaya orang lain tanpa adanya filterisasi. Modernisasi yang identik dengan perkembangan ilmu pengetahuan dan teknologi dapat membawa dampak positif dan negatif. Dampak positif yang dapat dirasakan yaitu dapat mengurangi beban aktifitas 
manusia dengan adanya alat yang serba canggih dan juga dapat membuka cakrawala berpikir yang lebih terbuka, inklusif serta canggih dengan banyaknya informasi yang diterima. Sedangkan dampak negatif dari modernisasi adalah masuknya budaya-budaya asing melalui media informasi yang lepas batas tanpa adanya upaya penyaringan (filterisasi).

Sebagian masyarakat Madura adalah bersifat imitatif, yaitu masyarakat yang berkecenderungan untuk meniru budaya orang lain. Budaya asing yang tidak membatasi hubungan laki-laki dan perempuan telah masuk melalui media televisi, video, VCD, internet atau semacamnya yang cenderung mempengaruhi generasi muda dengan berbagai motif yang sangat menggiurkan, banyak generasi muda di Madura yang meniru motif tersebut, kemudian mempraktikkan dalam kehidupan kesehariannya, termasuk di dalamnya adalah hubungan antara laki-laki dan perempuan yang bukan mahram.

Kelima, adanya rasa ketakutan terhadap putusnya ikatan peminangan sehingga berakibat batalnya pernikahan. Peminangan merupakan suatu ikatan yang terjadi sebelum perkawinan. Dalam peminangan biasanya dilakukan suatu janji atau kesepakatan kedua belah pihak (laki-laki dan perempuan) untuk melangsungkan perkawinan. Tidak jarang janji yang pernah dilakukan pada masa peminangan secara konsisten terlaksana dengan baik, dan tidak sedikit pula yang mengalami pembatalan ikatan peminangan, artinya janji kawin yang pernah disepakati bersama menjadi tidak terwujud diakibatkan oleh suatu hal yang menuntut agar perkawinan dibatalkan.

Yang menjadi penyebab putusnya ikatan peminangan seringkali karena masalah sepele. Suatu contoh, laki-laki yang berkehendak untuk ngobrol dengan perempuan tunangannya kemudian perempuan tersebut tidak mempedulikannya maka laki-laki yang bersangkutan merasa jengkel kemudian berupaya untuk memutuskan ikatan peminangan.

Peristiwa ini seringkali terjadi di Madura, sehingga lakilaki dan perempuan yang dalam ikatan peminangan lebih 
waspada agar ikatannya tetap utuh sampai memasuki jenjang perkawinan. Kewaspadaan yang dilakukan diwujudkan dalam bentuk selalu memenuhi kehendak dari masing-masing pihak, baik pihak laki-laki kepada pihak perempuan maupun sebaliknya, sekalipun kehendak tersebut tidak sejalan dengan ketentuan peminangan dalam perspektif hukum Islam.

\section{Praktik Khithbah di Madura dalam Pandangan Hukum Islam.}

Sebagaimana disinggung di awal bahwa hukum Islam mengatur mengenai peminangan yang didasarkan pada alQur'an, Hadits dan pendapat ulama' yang terdapat dalam kitab fikih. al-Qur'an menjelaskan secara eksplisit tentang peminangan yang diperbolehkan menurut hukum Islam, sebagaimana yang disitir dalam surat al-Baqarah ayat 235. Berdasarkan penjelasan 'Ali al-Shabuni dalam Tafsir "Rawai'ul Bayan" bahwa ayat ini menjelaskan kebolehan bagi laki-laki untuk meminang perempuan yang dalam masa 'iddah karena ditalak atau ditinggal mati suaminya, namun khithbah tidak boleh dilakukan secara terang-terangan melainkan secara sindiran. Keterangan ini menunjukkan bahwa secara gamblang al-Qur'an menjelaskan tentang tata cara peminangan yang dibenarkan menurut hukum Islam, kendatipun apa yang dijelaskan dalam al-Qur'an masih bersifat umum atau global.

Di samping yang terdapat dalam al-Qur'an, hadits juga menjelaskan dengan penjelasan yang lebih lengkap mengenai peminangan menurut hukum Islam. Hadits Nabi saw. menganjurkan bagi laki-laki yang menyenangi atau tertarik kepada seorang perempuan dikarenakan suatu hal yang dapat menarik simpati laki-laki tersebut, maka bersegeralah untuk meminang perempuan itu dengan niatan yang tulus (untuk nikahi).

Ketertarikan laki-laki kepada perempuan dikarenakan beberapa kelebihan yang dimiliki perempuan. Kelebihan tersebut bersifat subjektif, dalam artian sesuai dengan kehendak laki-laki yang bersangkutan, baik berupa kecantikannya, 
kekayaanya, kemolekan tubuhnya maupun yang lainnya. Namun, dalam hal ini Rasulullah saw. menganjurkan kepada kita agar seyogyanya mengawini perempuan karena 4 hal, yaitu karena kekayaan, keturunan, kecantikan, dan agamanya. Dari keempat hal tersebut yang harus menjadi prioritas utama adalah agama, karena agama merupakan hal yang nomor satu, tanpa agama manusia akan terjerembab pada jurang kenistaan.

Dalam Islam juga diajarkan tentang tata cara melakukan peminangan yang Islami sebagaimana hasil penelitian yang telah dipaparkan di awal yang salah satunya adalah cara melihat perempuan yang dipinang. Menurut penulis, dalam proses peminangan justru menjadi keharusan yang hendak dipinang, karena tidak mungkin kita akan melamar perempuan yang tidak diketahui orangnya (kecantikannya), hal ini ditakutkan menimbulkan kekecewaan yang mendalam, baik oleh pihak laki-laki maupun perempuan setelah ikatan perkawinan dilakukan.

Kebolehan melihat perempuan yang hendak dipinang sebatas melihat pada bagian anggota badan yang telah ditentukan oleh syara'. Menurut kesepakatan ulama' batas kebolehan tersebut hanya pada wajah dan kedua telapak tangan. Melihat bagian anggota yang melebihi batas yang ditentukan, maka dihukumi haram.

Berdasarkan keterangan di atas menunjukkan secara eksplisit maupun implisit tentang peminangan yang dibenarkan oleh hukum Islam. Namun hal ini secara praktis banyak yang tidak terwujud di Madura. Mereka melakukan praktik yang tidak sesuai dengan ketentuan hukum Islam. Salah satu contoh yang paling menonjol, bahwa peminangan yang seharusnya dilakukan dengan cara yang tidak mengandung dosa, yaitu dengan melihat perempuan yang akan dipinang hanya sebatas pada wajah dan kedua telapak tangan (menurut jumhur ulama'), namun masyarakat di Madura tidak mempraktikkan sebagaimana ketentuan tersebut, mereka melihat perempuan pinangan lebih pada selain wajah dan telapak tangan sehingga 
peminangan yang dilakukan cenderung pada perbuatan dosa dan tidak menampakkan nilai-nilai yang Islami.

\section{Penutup}

Dalam realitasnya praktik khithbah yang dilakukan masyarakat di Madura secara mayoritas lebih menonjolkan hukum adat atau secara konkrit lebih menggunakan tradisi dan kebiasaan yang berlaku di masyarakat. Dengan kata lain dapat dinyatakan, terkadang mengesampingkan hukum Islam.

Kendati demikian, praktik khithbah yang dilakukan oleh masyarakat Madura tidak secara totalitas menampakkan praktik yang tidak Islami. Namun masih banyak sebagian yang lain yang justru sangat kental dengan nilai-nilai keagamaan. Terutama bagi mereka yang mengerti ajaran agama, misalnya dari kalangan santri atau kalangan tertentu, mereka kerap sekali dengan praktik khithbah yang Islami sesuai dengan hukumhukum syari'ah.

Tulisan yang telah dijabarkan di awal, bukan dengan maksud untuk menodai atau menggerogoti, apalagi menjelekkan kehormatan masyarakat Madura. Akan tetapi dalam ranah untuk membangun sinergitas para pemerhati hukum Islam, para tokoh agama, para akademisi dan praktisi hukum Islam agar seyogyanya terbangun untuk ikut andil memperbaiki kondisi masyarakat yang telah banyak menyimpang dari ajaran-ajarah syari'ah. Wallahu a'lam bi alShawab.

\section{Daftar Pustaka}

Abdullah, Pius \& Trisno Yuwono. Kamus Lengkap Bahasa Indonesia Praktis. Surabaya: Arkola, 1994.

Anshori al-, al-Sharqawi dan Zakaria. al-Sharqawi 'ala al-Tar, Juz 2. (Jeddah: al-Nashru wa at-Tauzi', tt.

As'ad, Abd al-Muhaimin. Risalah Nikah Penuntun Perkawinan. Jakarta: Bintang Terang, 1993. 
Askalani al-, Ibnu Hajar. Bulugh al-Maram. Surabaya: alHidayah, $852 \mathrm{H}$.

Bakar, Imam Taqiyuddin Abu. Kifayatu al-Akhyar fi Halli Ghayati al-Ikhtisar, Juz 2. Bandung: Pustaka al-Ma'arif, tt.

Buraidah, Abu dan M. Fauzi. Meminang dalam Islam. Jakarta: Pustaka al-Kautsar, 2009.

Chafidh, M. Afnan dan A. Ma'ruf Asrori. Tradisi Islami, Panduan Prosesi Kelahiran, Perkawinan, Kematian. Surabaya: Khalista, 2006.

Departemen Urusan Agama Islam Wakaf, Da'wah dan Irshad, al-qur'an dan Terjemahnya. Makkah Saudi Arabia: al-Malik Fadh li al-Thiba' al-Mushhaf al-Sharif, 1994.

Depdikbud. Kamus Besar Bahasa Indonesia. Jakarta: Balai Pustaka, 1989.

Ghifari al-, Abu. Pacaran Yang Islami, Adakah?. Bandung: Mujahid, 2003.

Gymnastiar, Abdullah. Meraih Bening Hati dengan Manajemen Qolbu. Jakarta: Gema Insani, 2002.

Malibari al-, Zainuddin bin Abdul Aziz. Fathu al-Mu'in. Surabaya: tp.,tt.

Marhijanto, Kholilah. Menciptakan Keluarga Sakinah. Jakarta: Bintang Remaja, tt.

Mas'adi, A. Ghufron A. Pemikiran Fazzlur Rahman tentang Metodologi Pembaharuan Hukum Islam. Jakarta: RajaGrafindo Persada, 1997.

Munawwir, Ahmad Warson. Kamus Al-Munawwir. Surabaya: Pustaka Progressif, 1997.

Muslim, Abi Husein. Shahih Muslim. Beirut: Dar al-Fikr, 1988.

Rusyd, Ibnu. Bidayatu al-Mujtahid wa Nihayatu al-Muqtasid, terj. Imam Ghazali Said, Ahmad Zaidun. Jakarta: Pustaka Amani, 2007.

Sâbiq, Sayyid. Fiqh al-Sunnah, Juz 2. Beirut: Dar al-Fatah al'Arabi, 1999.

Saebani, Beni Ahmad. Fiqh Munakahat 1. Bandung: Pustaka Setia, 2009. 
Shabuni al-, 'Ali. Rawai'u al-Bayan. Beirut: Maktabah al-Ghazali, $448 \mathrm{H}$.

Shafi'i al-. al-Umm, Juz VIII, terj. Ismail Yakub. Jakarta: Faizan, 1984.

Shan'ani al-, Muhammad ibn Isma'il al-Amir. Subul al-Salam, Juz 3. Beirut: Dar al-Kutub al-'Ilmiyah, 1971.

Sitanggal, Ashari Umar. Fiqh Wanita. Semarang: as-Syifa', 1981. Syifa', 1994. . Fiqih Syafi'i Sistematis. Semarang: as-

Thalib, M. 15 Tuntunan Meminang Islami. Bandung: Irshad Bait al-Salam, 1999. 1993.

Tim Redaksi Tanwir al-Afkar. Fikih Rakyat Pertautan Fikih dengan Kekuasaan. Yogyakarta: LKiS, 2000.

Uman, Kholil dan Erni Fauziana. Petunjuk Menuju Keluarga Bahagia. Surabaya: Penerbit Indah, 1997.

Uthman, Abd. al-Rahman Muhammad. Ainu al-Ma'bud, Juz VI. Beirut: Dar al-Fikr, tt.

Wigdjodiporo, Soerojo. Pengantar dan Asas-Asas Hukum Adat. Jakarta: PT. Toko Gunung Agung, 1968.

Zuhailī al-, Wahbah. al-Figh al-Islāmi wa Adillatuh, Juz 7. Damaskus: Dār al-Fikr, 2010. 